\title{
Cyrtopodium paludicolum germination with two Tulasnella isolates
}

\author{
Otieres Cirino de Carvalho ${ }^{1}$, Vespasiano Borges de Paiva Neto ${ }^{2 *}$, Daly Roxana Castro Padilha1, Tomás Gomes \\ Reis Veloso ${ }^{3}$, Melissa Faust Bocayuva ${ }^{3}$, Deanna Carla Oliveira Soares ${ }^{1}$, and Maria Catarina Megumi Kasuya ${ }^{3}$
}

Received: May 11, 2017

Accepted: September 25, 2017

\begin{abstract}
Symbiosis between orchid seeds and mycorrhizal fungi has been reported to be a determining factor in the success of germination and protocorm development in vitro. The aim of this study was to isolate and identify by molecular analysis the mycorrhizal fungus associated with Cyrtopodium paludicolum, and to evaluate its efficiency in facilitating seed germination and development. Germination experiments were carried out using a fungus isolated from $C$. paludicolum (CH01) and Epidendrum secundum (M65), which has been successfully used a number of times in symbiotic germination. The experiments were conducted in a completely randomized design with treatments of $\mathrm{CH} 01, \mathrm{M} 65$ as well as under asymbiotic conditions. The mycobiont $\mathrm{CH} 01$ was successfully isolated from Cyrtopodium paludicolum and identified as Tulasnella sp. Treatments with both fungi reached a higher germination percentage than under asymbiotic conditions, indicating no specificity in the relationship between Cyrtopodium paludicolum and the fungi. The results presented have the potential to advance research into the propagation and conservation of $C$. paludicolum, a native of the Cerrado biome.
\end{abstract}

Keywords: Cerrado, ITS-DNAr, mycorrhiza, Orchidaceae, symbiosis

\section{Introduction}

Orchids of the Cyrtopodium genus are renowned for the beauty of their structures at both the vegetative and reproductive stages, due to their large pseudobulbs, exuberant foliage and long stalks with their displays of richly colored flowers, which offer significant potential for commercial exploitation. However, according to Batista \& Bianchetti (2006) and Rodrigues et al. (2015), despite this potential for commercial floriculture and the therapeutic value of their pseudobulbs, many Cyrtopodium species are unknown in the commercial market, or lack efficient propagation protocols.

Cyrtopodium paludicolum belongs to the Epidendroideae subfamily, the Cymbidieae tribe and the Catasetinae subtribe
(Chase et al. 2003). It is a terrestrial species and is found only in land areas subject to frequent flooding, in the midwestern and southeastern regions of Brazil. The pseudobulbs are long and can reach up to $40 \mathrm{~cm}$. The flower stalk may reach up to $2 \mathrm{~m}$ in height, having a simple inflorescence (rarely branched), with yellow colored flowers, measuring about $3.8 \mathrm{~cm}$ in diameter. The flowering season is from December to April (Menezes 2000).

Cyrtopodium paludicolum has small seeds and, according to Arditti \& Ghani (2000), orchid seeds are the smallest in the plant kingdom. Furthermore, despite the large number of seeds produced, seed germination is extremely low (less than $1 \%$ ) in orchids, because their embryos lack access to nutrient reserves, and successful germination of seeds in vivo is required for fungal stimulus (mycotrophy). This symbiosis

1 Universidade Federal de Mato Grosso do Sul, Campus de Chapadão do Sul, P.O. Box. 112, 79560-000, Chapadão do Sul, MS, Brazil

2 Universidade Federal do Vale do São Francisco, Campus de Ciências Agrárias, BR 407 - KM 119 - 543 PSNC, s/n - C1, 56300-990, Petrolina, PE, Brazil

3 Laboratório de Associações Micorrízicas, Universidade Federal de Viçosa, Campus Universitário, Av. P.H. Rolfs, 36570- 900, Viçosa, MG, Brazil

* Corresponding author: vespasiano.paiva@univasf.edu.br 
is characterized mainly by the formation of complex hyphal coils (pelotons) within host plant cells, i.e., the cortical parenchyma cells of the root or embryo (Dearnaley 2007).

Symbiotic seed germination techniques represent an efficient way of promoting orchid-fungus association under in vitro conditions and of studying in vitro orchid mycobiont specificity (Zettler 1997; Stewart \& Kane 2006). Culture media usually employed in the asymbiotic germination of orchid seeds under in vitro conditions are composed of agar, macro and micronutrients, vitamins, sugar. Occasionally, plant growth regulators can be added. Symbiotic germination media usually contain agar and any other ingredient with a complex carbohydrate source of fungus nutrition such as oatmeal (Guimarães et al. 2013; Jiang et al. 2015), potato (Pereira et al. 2014), and corn meal (Zettler et al. 2011).

Cyrtopodium paludicolum has aroused the interest of collectors and informal marketers of plants, resulting in intense gathering of this species, which increases the risk of extinction for this orchid. It is not an endangered species, and has been classified in the "Least Concern" category in The Red Book of Brazilian Flora (Martinelli \& Moraes 2013). The threatening processes facing orchids are primarily anthropogenic, most often resulting directly from habitat destruction, modification and fragmentation, and in a number of regions, over-collection (Swarts \& Dixon 2009).

The present study aimed to isolate and identify mycorrhizal fungus associated with $C$. paludicolum roots. We also aimed to promote seed germination using two Tulasnella spp. isolates, and compare the efficiency of an endophyte from $C$. paludicolum with an efficient mycorrhizal fungus in symbiotic germination.

\section{Materials and methods}

\section{Plant material}

Two adult plants of $C$. paludicolum Hoehne LC with mature capsules were selected and collected for this study. Sampling was carried out at the Catapani farm situated in the municipality of Costa Rica, in the state of Mato Grosso do Sul, Brazil (SISBIO permit 22570-2). Plants were cultivated in plastic pots, using Plantmax - with HT as substrate, and kept in a greenhouse under daily irrigation. For species identification procedures, vouchers were prepared and deposited in the herbarium of the Instituto de Botânica, São Paulo, in the state of Sao Paulo, Brazil.

The mature capsules resulting from natural pollination were collected, disinfected and opened for removal of the seeds, which were mixed and deposited in test tubes containing silica gel and then stored in a refrigerator at $4^{\circ} \mathrm{C}$ for later use in both symbiotic and asymbiotic seed germination.

The roots were collected from donor plants and immediately transferred to a laboratory for isolation procedures.

\section{Isolation}

Isolation procedures were implemented following Otero et al. (2002) and Valadares et al. (2012). Young, fresh and healthy roots representing a part of the active root system were cut into $3 \mathrm{~cm}$ segments and placed into Petri dishes with moistened filter paper and were taken to the laboratory where they were washed in tap water, and again in distilled water. These fragments were superficially disinfected by washing in ethanol $(70 \%, v / v)$ for $1 \mathrm{~min}$, and 6 min in sodium hypochlorite solution $(0.5 \%$ active chlorine), followed by fivefold washings with sterilized water, and shaken by hand. Superficial disinfecting of root segments was carried out in a laminar flow chamber and thin transversal sections were excised using a scalpel under stereomicroscopy. Five small groups of the colonized root cortical cells were removed by hypodermic needle. The fragments containing pelotons were transferred to sterile Petri dishes containing $50 \mathrm{~mL}$ of potato dextrose agar (PDA) medium, $\mathrm{pH}$ 5.6, and were kept in an incubator - BOD $\left(0 / 24 \mathrm{~h}\right.$ day/night photoperiod, $\left.28 \pm 2{ }^{\circ} \mathrm{C}\right)$. The cortical cell fragments were examined daily for the presence of fungal growth, and hyphal tips were excised and transferred to a fresh PDA for morphological identification, DNA extraction for molecular analysis, and symbiotic seed germination. The isolate acquired has been cultured in PDA petri dishes and maintained in BOD (night photoperiod, $28^{\circ} \mathrm{C}$ ) at the Laboratório de Fisiologia Vegetal, Universidade Federal do Vale do São Francisco (CCA/UNIVASF).

\section{DNA extraction and rDNA sequencing}

Petri plates with samples of the mycorrhizal fungus $\mathrm{CH} 01$ isolate from C. paludicolum were sent to the Laboratório de Associações Micorrízicas at the Universidade Federal de Viçosa for submission to molecular identification procedures. Initially, the fungal mycelium was lyophilized and total DNA extraction was performed with NucleoSpin ${ }^{\circledR}$ Soil Kit (Macherey-Nagel) in accordance with the manufacturer's instructions. For the evaluation of DNA integrity, an agarose gel $(0.8 \%)$ was used and quantification was determined by spectrophotometry. The DNA extracted was submitted to PCR amplification using ITS1-ITS4 primers (White et al. 1990) to amplify the ITS1-5.8S-ITS2 region of the fungus ribosomal DNA (rDNA), and the reaction conditions described by Gardes \& Bruns (1993). PCR products were purified using Exo-Sap (USB Corporation, Cleveland, Ohio), as recommended by the manufacturer. Both strands (forward and reverse) were sequenced by the Macrogen Inc. Company (South Korea). Amplified ITS sequences were assembled and edited using the Sequencher software program version 4.5 (GeneCodes, Ann Arbor, USA). Subsequently, the sequences were aligned and for application of the Mega software program version 4.0 (Tamura et al. 2007). Random representative sequences were selected and 
searched with the BLASTn algorithm (Altschul et al. 1997) to select sequences from the NCBI database (GenBank, http://www.ncbi.nlm.nih.gov).

\section{Symbiotic and asymbiotic seed germination}

To evaluate the germination percentage and protocorm development, seeds previously stored for 15 days were submitted to a disinfection procedure. They were immersed in a sodium hypochlorite solution ( $0.5 \%$ active chlorine) for 10 minutes followed by threefold washing in distilled and autoclaved water.

For the germination test, the disinfected seeds were kept in suspension in $50 \mathrm{~mL}$ of sterile water. Four hundred microliters were scattered on a filter paper disc (Germitest ${ }^{\circ}, 6$ $\mathrm{cm}$ diameter), placed in the center of a Petri dish containing $20 \mathrm{~mL}$ of a modified oat-agar culture medium (Dixon 1987) with $4 \mathrm{~g} \mathrm{~L}^{-1}$ oatmeal and $10 \mathrm{~g} \mathrm{~L}^{-1}$ agar (HiMedia ${ }^{\circledR}$ ), and added to $2 \mathrm{~g} \mathrm{~L}^{-1}$ activated charcoal with the $\mathrm{pH}$ adjusted to 5.6. The filter paper disk served as a receptor of the seeds, which isolated the seeds from initial excess moisture in the culture medium. For symbiotic germination, each plate was inoculated with a $5 \mathrm{~mm}$ diameter disc of fungal inoculum, one fungal mycobiont per plate (CH01 or M65), and a total of six replicate Petri dishes per mycobiont. Six uninoculated plates served as the control, i.e., asymbiotic treatment. The mycoboint M65 (Pereira et al. 2009) was a Tulasnella sp. from the orchid mycorrhizal fungi collection of the Laboratório de Associações Micorrízicas (BIOAGRO / UFV). M65 was subcultured once and maintained in BOD at room temperature before use in the germination experiment, showing satisfactory growth after the subculture step.

Petri dishes were sealed with PVC film (Dispafilm do Brazil Ltda) and then placed in a growth room (16/08h day/ night photoperiod, $27 \pm 2^{\circ} \mathrm{C}$ ). Irradiance, supplied by cool white fluorescent bulbs, was measured at $40 \mu \mathrm{mol} \mathrm{m}^{-2} \mathrm{~s}^{-1}$. The seed stage development was carried out $30 \mathrm{~d}$ after seed sowing using a stereomicroscope. Seed germination and development were assessed on a scale of $0-2$ modified from Bektas et al. (2013) as follows: stage 0: seeds with viable and unswollen embryo, intact seed coat, no germination; stage 1: seeds with swollen embryo but without seed coat rupture, no germination; stage 2: swollen embryo with seed coat rupture, rhizoid presence or absence, germination. The germination percentage was calculated by dividing the number of seeds at stage 2 by the total number of seeds multiplied by 100 . The growth index of the seeds was calculated using the following formula (Otero et al. 2005): $\mathrm{GI}=\left(\mathrm{N}_{1}+\mathrm{N}_{2} \cdot 2\right) /\left(\mathrm{N}_{0}+\mathrm{N}_{1}+\mathrm{N}_{2}\right)$, with $\mathrm{GI}$ as the growth index; and $\mathrm{N}_{0}$ as the number of seeds at stage $0, \mathrm{~N}_{1}$ the number of seeds at stage 1 , and $\mathrm{N}_{2}$ the number of seeds at stage 2 .

The data collected were submitted to a one-way ANOVA with an F-test and a comparison of averages by Tukey test at the $5 \%$ significance level, using the Sisvar program (Ferreira 2011). Germination data were arcsine transformed to normalize variations before statistical analysis.

\section{Microscopic analyses}

For light microscopic examination, fungal hyphae growing on PDA, and root cross sections from adult orchid and cross sections in protocorm obtained from symbiotic germination (CH01) were individually mounted on a microscopic slide, covered with a cover slip and examined under a light microscope (Nova Optical Systems) coupled with a digital camera (Sony Cyber-shot). Sections were cut by hand and tissues were stained with Alcian blue and safranin in combination in all cases.

For the Scanning Electron Microscope (SEM) the protocorms were subjected to an ethanol dehydration process (from 5 to $95 \% \mathrm{v} / \mathrm{v}, 1$ h each) after which manual cross sections were cut by hand using a razor blade. All cuts were kept in a kiln $\left(35^{\circ} \mathrm{C}\right.$ for $\left.24 \mathrm{~h}\right)$. The histological sections were positioned on stubs prior to gold sputtering in a Sputter Coater (Balzer FDU010). Following coating with a thin layer of gold (about $20 \mathrm{~nm}$ ), the specimens were observed and micrographed using a TEM at $15 \mathrm{kV}$.

\section{Results and discussion}

\section{Isolation and identification of mycorrhizal fungus}

The presence of peloton was detected in the root cortex cells collected from vegetative adult plants of transversally sectioned C. paludicolum (Fig. 1A), confirming the symbiotic status of $C$. paludicolum. After the isolation process, only one endophyte, named $\mathrm{CH} 01$, was recovered from pelotons extracted from the root cortical parenchyma cells of $C$. paludicolum (Fig. 1B). On PDA, the colony appeared white and cottony with radial growth, aerial thin hyphal growth (Fig. 1B), and a vegetative hyphae septate right-angle branching pattern of hyphae with constriction at branching prints, as well as monilioid cells which were thin walled and barrel shaped, with nearly spherical branched chains (Fig. 1C).

Molecular analysis by ITS region characterization of the isolated mycorrhizal fungus from C. paludicolum showed that the isolate $\mathrm{CHO1}$ had a high homology level (94 \%) with the Tulasnella genus, and it was registered as code KP973894 (Tab. 1). The sequence obtained from the isolate clustered with known Rhizoctonia sequences was retrieved from the Genbank. Tulasnella consists of filamentous fungi containing saprophytic species. Additionally, mycorrhizal fungi in orchid are one of the teleomorphic phases of the form-genus Rhizoctonia, an important symbiont genus in orchids (Mosquera-Espinosa et al. 2010). Integration of morphological characterization and ITS analysis have been used as more accurate identifiers of fungi (Cruz et al. 2011; Valadares et al. 2012).

Rhizoctonia-like fungi are difficult to classify due to the scarcity of sexual sporulation necessary to a definition of teleomorphic genera as Ceratobasidium, Thanatephorus, 

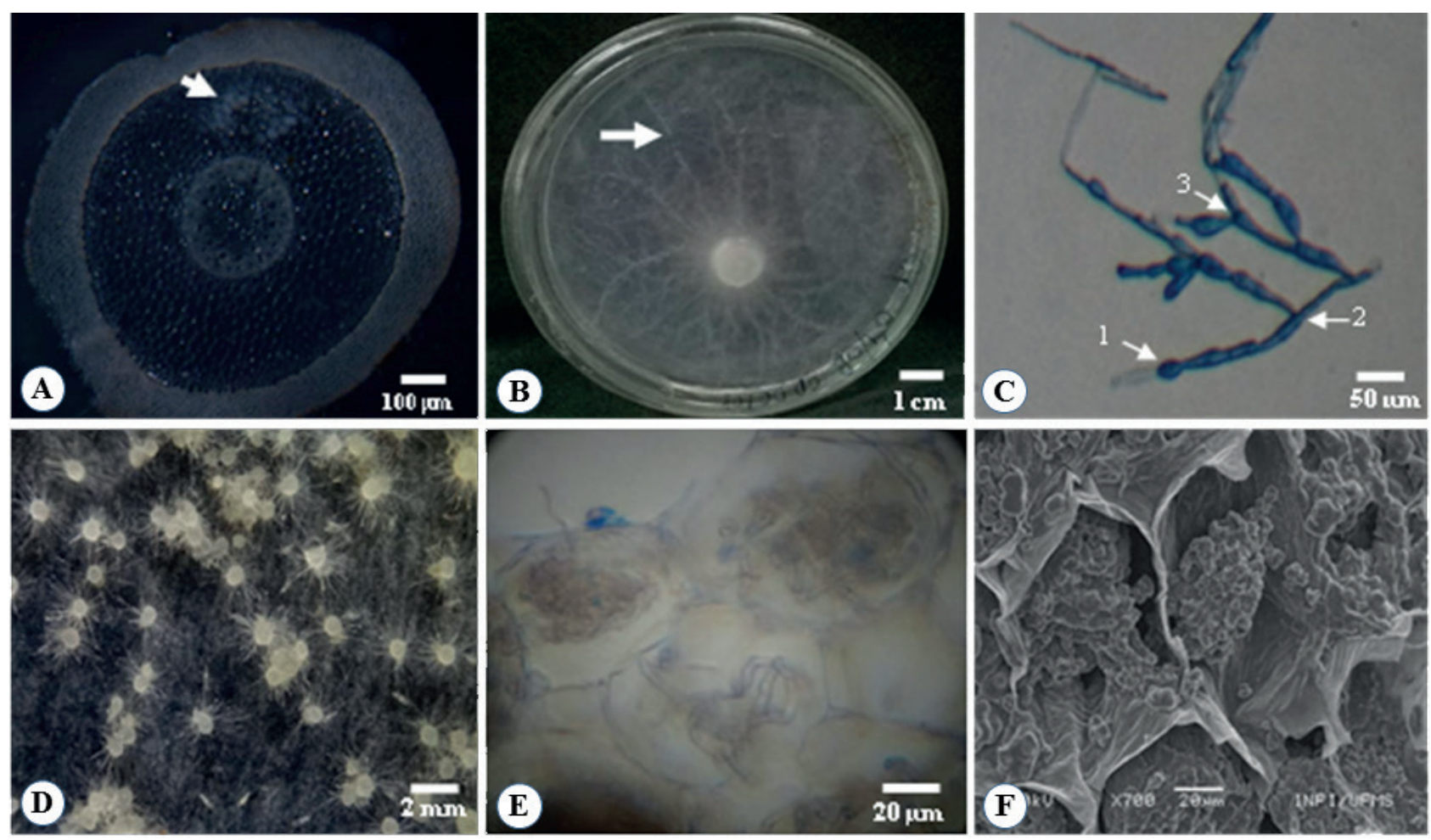

Figure 1. Transversal root section of Cyrtopodium paludicolum showing endophyte (arrow) presence in cortical parenchyma cells (A); CH01 fungus isolated on PDA medium with well development hyphae (B); Fungal hyphae with arrows indicating the presence of the monilioid cells (1), a right-angle branching (2), a constriction at the branch point and a septum in the branch hypha near its point of origin (3); (C); symbiotically raised protocorms (stage 2) with CH01 (D); optical (E) and scanning electronic (F) microscopies images showing colonized cortical parenchyma cells from C. paludicolum protocorms cultivated in symbiotic medium with CH01 isolate.

Tulasnella or Sebacina, and the morphological similarity of anamorphic genera to Ceratorhiza, Epulorhiza, Moniliopsis and Rhizoctonia in this artificial group (Currah et al. 1997; Roberts 1999). Consequently, molecular methods have become the standard means of assigning orchid fungi to groups within the Rhizoctonia alliance (Taylor et al. 2003; Shefferson et al. 2005), since these molecular methods enable a finer distinction of the strains compared to cytomorphological and ultrastructural characterizations (Dearnaley 2007).

Tulasnella has been found to be mycorrhizal in other orchid species, such as Spathoglottis affinis and Eulophia spectabilis (Chutima et al. 2011), Cymbidium goeringii and C. faberi (Yu et al. 2015). In Brazil, many isolated fungi from orchids belong to this respective anamorphic, the Epulorhiza genus, obtained from Epidendrum dendrobioides and Sophronitis milleri (Nogueira et al. 2005), Epidendrum secundum (Pereira et al. 2009; 2014; Nogueira et al. 2014), Acianthera limae and Polystachya concreta (Nogueira et al. 2014) and Cyrtopodium vernum (Gonçalves et al. 2014).

After 30 days, seed germination in the symbiotic process resulted in three different development stages $(0,1,2)$, but only stage 2 was characterized as germinated seeds. Light and scanning electronic microscopical observations (Fig. 1E,
F, respectively) showed that fungal pelotons were present in nearly all cross-sections of sampled protocorms obtained by seed selection at stage 2 . These observations confirmed that the $C$. paludicolum protocorms were colonized by the $\mathrm{CHO1}$ isolate during the symbiotic germination process. Pelotons were distributed throughout the cortex, with no difference between protocorm cortical layers (Fig. 1E, F). TEM observations also confirmed the known mycorrhizalprotocorm interaction, showing degenerating hyphae attached to collapsed pelotons in SEM images (Fig. 1F). Suárez et al. (2006) also described the presence of degenerated hyphae, though in an active root cortical cell of Stelis concinna.

The simple presence of fungi in orchid roots does not necessarily indicate functional association. These fungi will need to be isolated and grown in orchid seedlings before they can be designated as mycorrhizal partners (Dearnaley 2007). Additionally, Bonnardeaux et al. (2007) affirmed that symbiotic germination remains the only practical method available for confirming compatibility between orchids and fungi. They found that symbiotic germination tests, in combination with accurate fungal identification, provided more information about the specificity of orchid fungi relationships than either method alone would have provided. 
Table 1. Phylogenetic affiliation of operational taxonomic units (OTUs) based on fungal ITS1-ITS4 primers to amplify the ITS1-5.8SITS2 region of the fungus ribosomal DNA (rDNA).

\begin{tabular}{c|c|c|c|}
\hline \multirow{2}{*}{ Sequence length $(\mathrm{pb})$} & \multicolumn{3}{|c|}{ Filogenetic relations } \\
\cline { 2 - 4 } & Family & GenBank accession number & Sequence identity $(\%)$ \\
\hline 575 & Tulasnellaceae & KP973894
\end{tabular}

\section{Germination tests}

Both the M65 and CH01 fungi examined in this study significantly increased the seed germination percentages and growth index of the C. paludicolum protocorms compared to the asymbiotic treatment (Tab. 2), irrespective of their origin. These results indicate that symbiotic inoculation with either mycorrhizal fungi $\mathrm{CH} 01$ or M65 was beneficial to the germination, but additional experiments will be necessary to confirm if these benefits also extend to protocorm development of $C$. paludicolum.

The fact that the germination percentage of both symbiotic treatments ( $\mathrm{CHO1}$ and M65) are similar, leads to the inference that there is no specific relationship between C. paludicolum and the two symbionts. Consequently, the M65 endophyte, isolated from other orchid species, can be considered compatible with C. paludicolum. A compatibility relationship is usual in orchid symbiosis and similar results were obtained by Chutima et al. (2011), in an experiment on the symbiotic germination of Pecteilis susannae seeds, using different mycorrhizal fungi, including three obtained from their own orchid. These authors observed that the average percentage germination and development obtained by using their own isolated species were no different from the averages obtained by using another isolate from Eulophia spectabilis. Additionally, Pereira et al. (2015) suggested that Cyrtopodium glutiniferum has a preference for strains of Tulasnella and that fungus digestion is essential to protocorm development. In contrast, these authors observed that the isolates of Ceratorhiza and Rhizoctonia did not promote germination in Cyrtopodium glutiniferum seeds.

An understanding of the specificity in orchid mycorrhizal association is essential to the establishment of conservation strategies based on symbiotic propagation (Zettler 1997; Fracchia et al. 2014). Once orchids have been symbiotically propagated they have a higher survival rate when they are transplanted ex vitro (Ramsay \& Dixon 2003). A lot of research needs to be done to unravel the underlying mechanism of mycorrhizal associations in orchids which may then help to prevent their decline and extinction in nature (Aggarwal et al. 2012).

Finally, the results of this research may contribute to the production of plants most likely to adapt to the natural environment which can be used in conservation programs through reintroduction into the Cerrado biome, subject to continuous degradation as a consequence of the impact of human activity. As part of our future intentions related to our research, we will investigate seedling acclimatization, the time required to further plant growth, and an evaluation
Table 2. Seed germination and growth index (GI) of the Cyrtopodium paludicolum protocorms, 30 days after in vitro cultivation on $16 / 0$ photoperiod in growth room ambient, in the absence (control) or in the presence of the fungi Tulasnella CH01 or M65.

\begin{tabular}{|c|c|c|}
\hline Mycorrhiza treatment & Germination $(\%)^{1}$ & GI \\
\hline Control & $34.44 \mathrm{~b}$ & 0.91 \\
\hline CH01 & $52.89 \mathrm{a}$ & 1.16 \\
\hline M65 & $48.04 \mathrm{a}$ & 1.09 \\
\hline
\end{tabular}

${ }^{1}$ Values followed by the same letter are not significantly different according to Tukey's multiple range test $(\mathrm{P}=0.05)$.

of the survival rate in nature. These actions are necessary to ensure the success of future conservation programs of Cyrtopodium paludicolum and other native orchid species in the Cerrado.

\section{Conclusions}

An endophytic fungus belonging to the genus Tulasnella was isolated from C. paludicolum roots. Cyrtopodium paludicolum seeds are not specific to the fungus obtained, $\mathrm{CH} 01$. Symbiotic germination is beneficial compared to asymbiotic germination. $\mathrm{CH} 01$ showed similar contributions to seed germination compared to isolated M65, a fungus with proven success in seed germination.

\section{Acknowledgements}

We extend our gratitude to the Fundação de Apoio ao Desenvolvimento do Ensino, Ciência e Tecnologia do Estado de Mato Grosso do Sul (FUNDECT) for financial support. We also thank the Universidade Federal de Mato Grosso do Sul - UFMS (Campo Grande, MS) for the use of the SEM and their facilities.

\section{References}

Aggarwal S, Nirmala C, Beri S, Rastogi S, Adholeya A. 2012. In vitro symbiotic seed germination and molecular characterization of associated endophytic fungi in a commercially important and endangered Indian orchid Vanda coerulea Griff. ex Lindl. European Journal of environmental Sciences 2: 33-42.

Altschul SF, Madden TL, Schäffer AA, et al. 1997. Gapped BLAST and PSI-BLAST: a new generation of protein database search programs. Nucleic Acids Research 25: 3389-3402.

Arditti J, Ghani AKA. 2000. Numerical and physical properties of orchid seeds and their biological implications. New Phytologist 145: 367-421.

Batista JAN, Bianchetti LB. 2006. A new species of Cyrtopodium (Orchidaceae) from the Cerrado of Central Brazil. Novon 16: 17-22. 


\section{Otieres Cirino de Carvalho, Vespasiano Borges de Paiva Neto, Daly Roxana Castro Padilha, Tomás Gomes Reis Veloso, Melissa Faust Bocayuva, Deanna Carla Oliveira Soares and Maria Catarina Megumi Kasuya}

Bektas E, Cüce M, Sökmen A. 2013. In vitro germination, protocorm formation, and plantlet development of Orchis coriophora (Orchidaceae), a naturally growing orchid species in Turkey. Turkish Journal of Botany 37: 336-342.

Bonnardeaux Y, Brundrett M, Batty A, Dixon K, Koch J, Sivasithamparam K. 2007. Diversity of mycorrhizal fungi of terrestrial orchids: compatibility webs, brief encounters, lasting relationships and alien invasions. Mycological Research 111: 51-61.

Chase MW, Cameron KM, Barrett RL, Freudenstein JV. 2003. DNA data and Orchidaceae systematics: a new phylogenetic classification. In: Dixon KW, Kell SP, Barrett RL, Cribb PJ. (eds.) Orchid conservation. Kota Kinabalu, Natural History Publications. p. 69-89.

Chutima R, Dell B, Lumyong S. 2011. Effects of mycorrhizal fungi on symbiotic seed germination of Pecteilis susannae (L.) Rafin (Orchidaceae), a terrestrial orchid in Thailand. Symbiosis 53: 149-156.

Cruz D, Suárez JP, Kottke I, Piepenbring M, Oberwinkler F. 2011. Defining species in Tulasnella by correlating morphology and nrDNA ITS$5.8 \mathrm{~S}$ sequence data of basidiomata from a tropical Andean Forest. Mycological Progress 10: 229-238.

Currah RS, Zettler LW, Mcinnis TM. 1997. Epulorhiza inquilina sp. nov. from Platanthera (Orchidaceae) and a Key to Epulorhiza species. Mycotaxon 61: 338-342.

Dearnaley JDW. 2007. Further advances in orchid mycorrhizal research. Mycorrhiza 17: 475-486.

Dixon K. 1987. Raising terrestrial orchids from seed. In: Harris WK. (ed.) Modern orchid growing for pleasure and profit. Adelaide, Orchid Club of South Australia. p. 47-100.

Ferreira DF. 2011. Sisvar: a computer statistical analysis system. Ciência e Agrotecnologia 35: 1039-1042.

Fracchia S, Silvani V, Flachsland E, Terada G, Sede S. 2014. Symbiotic seed germination and protocorm development of Aa achalensis Schltr., a terrestrial orchid endemic from Argentina. Mycorrhiza 24: 35-43.

Gardes M, Bruns TD. 1993. ITS primers with enhanced specificity for basidiomycetes - application to the identification of mycorrhizae and rust. Molecular Ecolology 2: 113-118.

Gonçalves FJ, Nunes CMC, Filippi MC, Araújo LG, Gonçalves LA, Sibov ST. 2014. Isolation and characterization of mycorrhizal fungi in Cyrtopodium vernum Rchb. F. \& Warm (Orchidaceae). Revista de Ciências Agrárias 57: 244-249.

Guimarães FAR, Pereira MC, Felicio CS, et al. 2013. Symbiotic propagation of seedlings of Cyrtopodium glutiniferum Raddi (Orchidaceae). Acta Botanica Brasilica 27: 590-596.

Jiang J-H, Lee Y-I, Cubeta MA, Chen L-C. 2015. Characterization and colonization of endomycorrhizal Rhizoctonia fungi in the medicinal herb Anoectochilus formosanus (Orchidaceae). Mycorrhiza 25: 431445.

Martinelli G, Moraes MA. 2013. Livro vermelho da flora do Brasil. 1st. edn. Rio de Janeiro, Instituto de Pesquisas Jardim Botânico do Rio de Janeiro.

Menezes LC. 2000. Orchids genus Cyrtopodium: Brazilian species. Brasília, Editora IBAMA.

Mosquera-Espinosa AT, Bayman P, Otero JT. 2010. Ceratobasidium como hongo micorrizico de orquideas em Colombia. Acta Agronomica 59: 316-326.

Nogueira RE, Berg C, Pereira OL, Kasuya MCM. 2014. Isolation and molecular characterization of Rhizoctonia-like fungi associated with orchid roots in the Quadrilátero Ferrífero and Zona da Mata regions of the state of Minas Gerais, Brazil. Acta Botanica Brasilica 28: 298-300.

Nogueira RE, Pereira OL, Kasuya MCM, Lanna MC, Mendonça M. 2005. Fungos micorrízicos associados a orquídeas em campos rupestres na Região do Quadrilátero Ferrífero, Minas Gerais, Brasil. Acta Botanica Brasilica 19: 417-424.
Otero JT, Ackerman JD, Bayman P. 2002. Diversity and host specificity of endophytic Rhizoctonia-like fungi from tropical orchids. American Journal of Botany 89: 1852-1858.

Otero JT, Bayman P, Ackerman JD. 2005. Variation in mycorrhizal performance en the epiphytic orchid Tolumnia variegata in vitro: the potential for natural selection. Evolutionary Ecology 19: 29-43.

Pereira MC, Coelho IS, Valadares RBS, et al. 2014. Morphological and molecular characterization of Tulasnella spp. fungi isolated from the roots of Epidendrum secundum, a widespread Brazilian orchid. Symbiosis 62: 111-121.

Pereira MC, Pereira OL, Costa MD, Rocha RB, Kasuya MCM. 2009 Diversidade de fungos micorrízicos Epulorhiza spp. isolados de Epidendrum secundum (Orchidaceae). Revista Brasileira de Ciência do Solo 33: 1187-1197.

Pereira MC, Rocha DI, Veloso TGR, et al. 2015. Characterization of seed germination and protocorm development of Cyrtopodium glutiniferum (Orchidaceae) promoted by mycorrhizal fungi Epulorhiza spp. Acta Botanica Brasilica 29: 567-574.

Ramsay M, Dixon KW. 2003. Propagation science, recovery and translocation of terrestrial orchids. In: Dixon KW, Kell SP, Barret RL, Cribb PJ. (eds.) Orchid conservation. Kota Kinabalu, Natural History Publications. p. 259-287.

Roberts P. 1999. Rhizoctonia-forming fungi. Kew, Whitstable Litho Printers.

Rodrigues LA, Paiva Neto VB, Boaretto AG, et al. 2015. In vitro propagation of Cyrtopodium saintlegerianum Rchb. f. (Orchidaceae), a native orchid of the Brazilian savannah. Crop Breeding and Applied Biotechnology 15: 10-17.

Shefferson RP, WEIß M, Kull T, Taylor DL. 2005. High specificity generally characterizes mycorrhizal association in rare lady's slipper orchids, genus Cypripedium. Molecular Ecology 14: 613-626.

Stewart SL, Kane ME. 2006. Symbiotic seed germination of Habenaria macroceratitis (Orchidaceae), a rare Florida terrestrial orchid. Plant Cell, Tissue and Organ Culture 86: 159-167.

Suárez JP, Weiß M, Abele A, Garnica S, Oberwinkler F, Kottke I. 2006 Diverse tulasnelloid fungi form mycorrhizas with epiphytic orchids in an Andean cloud forest. Mycological Research 110: 1257-1270.

Swarts ND, Dixon KW. 2009. Terrestrial orchid conservation in the age of extinction. Annals of Botany 104: 543-556.

Tamura K, Dudley J, Nei M, Kumar S. 2007. MEGA4: Molecular Evolutionary Genetics Analysis (MEGA) software version 4.0. Molecular Biology and Evolution 24: 1596-1599.

Taylor DL, Bruns TD, Szaro TM, Hodges SA. 2003. Divergence in mycorrhizal specialization within Hexalectris spicata (Orchidaceae), a nonphotosynthetic desert orchid. American Journal of Botany 90: 1168-1179.

Valadares RB, Pereira MC, Otero JT, Cardoso EJ. 2012. Narrow Fungal Mycorrhizal Diversity in a Population of the Orchid Coppensia doniana. Biotropica 44: 114-1222.

White TJ, Bruns T, Lee S, Taylor J. 1990. Amplification and direct sequencing of fungal ribosomal RNA genes for phylogenetics. In: Innis MA, Gelfand DH, Sninsky JJ, White TJ. (eds.) PCR Protocols: a guide to methods and applications. New York, Academic Press. p. 315-322.

Yu Y, Cui Y-H, Hsiang T, Zeng Z-Q, Yu Z-H. 2015. Isolation and identification of endophytes from roots of Cymbidium goeringii and Cymbidium faberi (Orchidaceae). Nova Hedwigia 101: 57-64.

Zettler LW. 1997. Terrestrial orchid conservation by symbiotic seed germination: techniques and perspectives. Selbyana 18: 188-194.

Zettler LW, Wood EM, Johnson LJAN, Kirk AK, Perlman SP. 2011. Seed propagation and re-introduction of the U.S. Federally endangered Hawaiian endemic, Platanthera holochila (Hbd.) Krzl. (Orchidaceae). European Journal of Environmental Sciences 1: 80-94. 